\title{
Evaluating the accuracy of ALS-based removal estimates against actual logging data
}

\author{
Ville Vähä-Konka ${ }^{1}$ (D) $\cdot$ Matti Maltamo ${ }^{1} \cdot$ Timo Pukkala $^{1} \cdot$ Kalle Kärhä $^{2}$ \\ Received: 24 February 2020 / Accepted: 15 July 2020 / Published online: 27 August 2020 \\ (C) The Author(s) 2020
}

\begin{abstract}
- Key message We examined the accuracy of the stand attribute data based on airborne laser scanning (ALS) provided by the Finnish Forest Centre. The precision of forest inventory data was compared for the first time with operative logging data measured by the harvester.

- Context Airborne laser scanning (ALS) is increasingly used together with models to predict the stand attributes of boreal forests. The information is updated by growth models. Information produced by remote sensing, model prediction, and growth simulation needs field verification. The data collected by harvesters on logging sites provide a means to evaluate and verify the accuracy of the ALS-based data.

- Aims This study investigated the accuracy of ALS-based forest inventory data provided by the Finnish Forest Centre at the stand level, using harvester data as the reference. Special interest was on timber assortment volumes where the quality reductions of sawlog are model predictions in ALS-based data and true realized reductions in the logging data.

- Methods We examined the accuracy of total volume and timber assortment volumes by comparing ALS-based data and operative logging data measured by a harvester. This was done both for clear cuttings and thinning sites. Accuracy of the identification of the dominant tree species of the stand was examined using the Kappa coefficient.

- Results In clear-felling sites, the total harvest removals based on ALS and model prediction had a RMSE\% of $26.0 \%$. In thinning, the corresponding difference in the total harvested removal was $42.4 \%$. Compared to logged volume, ALS-based prediction overestimated sawlog removals in clear cuttings and underestimated pulpwood removals.

- Conclusion The study provided valuable information on the accuracy of ALS-based stand attribute data. Our results showed that ALS-based data need better methods to predict the technical quality of harvested trees, to avoid systematic overestimates of sawlog volume. We also found that the ALS-based estimates do not accurately predict the volume of trees removed in actual thinnings.
\end{abstract}

Keywords Reliability $\cdot$ Airborne laser scanning $\cdot$ Operational forest inventory $\cdot$ Clear cutting $\cdot$ Thinning

\section{Handling Editor: Jean-Michel Leban}

Contribution of the co-authors VV did all computations, analyzed the results, and wrote the original manuscript. MM, TP, and KK supervised the research, commented, and revised the manuscript.

Ville Vähä-Konka

vilva@uef.fi

Matti Maltamo

matti.maltamo@uef.fi

Timo Pukkala

timo.pukkala@uef.fi
Kalle Kärhä

kalle.karha@storaenso.com

1 University of Eastern Finland, School of Forest Sciences, Yliopistokatu 7, P.O. Box 111, FI-80101 Joensuu, Finland

2 Stora Enso, Wood Supply Finland, P.O. Box 309, FI-00101 Helsinki, Finland 


\section{Introduction}

Combined use of airborne laser scanning (ALS), field plots, and predictive models is today the most important source of information in management-oriented inventories of Finnish forests (Maltamo and Packalén 2014). ALS is also a promising method in national forest inventories (Grafström and Hedström Ringvall 2013) and pre-harvest stand measurement (Peuhkurinen et al. 2007). In practical forest planning, information is required by tree species (Packalén 2009). Aerial imagery is often used to interpret tree species and other attributes that are difficult to predict from laser scanning data (e.g., Packalén and Maltamo 2007; Ørka et al. 2013).

Verifications of inventories have shown that inventories based on ALS data (Wallenius et al. 2012) can be more accurate than those obtained by using traditional field-based methods (Suvanto et al. 2005). In addition, both in the evaluation of tree species-specific attributes (e.g., Packalén and Maltamo 2007; Breidenbach et al. 2010) and in the measurement of individual tree attributes (e.g., Korpela et al. 2010; Vauhkonen 2010; Yao et al. 2012; Silva et al. 2016), the accuracy has been at least the same as in traditional field assessments. However, further research is needed to improve the accuracy of tree quality estimation in ALS-based forest inventory (Wallenius et al. 2012).

The Finnish Forest Centre collects, maintains, and distributes stand attribute information on Finnish forests (Finnish Forest Centre 2019a). The data are based on the combined use of field inventories and remote sensing. Models are used to predict timber volumes and update the data. Field plots are used as training data and ALS is used to generalize the results over large inventory areas. Due to the amendment of the Forest Information Act, which came into force in early March 2018, much information was made publicly available through the Metsään.fi service (https://www.metsaan.fi/).

Information on sawlog and pulpwood harvest removal by tree species is essential in timber sales and in the planning of harvesting operations. Information on the quality characteristics of trees is also important (Holopainen et al. 2013). When predicting timber assortments, the training data should have precise stand level information on sawlog and pulpwood removals, which can be measured in practice only by a harvester (Malinen et al. 2003).

Previous studies on the accuracy of ALS inventory have usually compared ALS-based stand attribute estimates with field measurements (e.g., Næsset 2007; Wallenius et al. 2012; White et al. 2013). The problem with these comparisons is that a part of the field "measurements" are model predictions. This is the case for example with timber assortment volumes, which are based on taper models and predicted quality deductions. There have also been some attempts to use harvester data for similar purposes (Siipilehto et al. 2016; Pesonen 2017). Harvester data have also been used as training data in the modeling of stand attributes such as volume, basal area, and diameter distribution, using laser scanning metrics as predictors (Bollandsås et al. 2011; Peuhkurinen et al. 2011; Holmgren et al. 2012; Barth and Holmgren 2013; Hauglin et al. 2018; Saukkola et al. 2019). For example, Bollandsås et al. (2011) studied the prediction of tree volume and quality characteristics in northeastern Norway.

Previous research on the use of harvester data in forest inventory purposes has so far been minor because the collection and combining harvester data with remote sensing information is tedious (Holopainen et al. 2013). Harvester data are collected for timber sales transactions and research needs are seldom taken into account. Besides, GPS positioning of harvester data has generally been inaccurate (Lindroos et al. 2015). However, Hauglin et al. (2018) recently presented an approach for improved GPS positioning with an average error in the tree location of about $1 \mathrm{~m}$.

In this study, we applied operational large-scale logging data and compared them with ALS-based stand attribute data in the Metsään.fi service. The most important characteristics compared were the total volume and tree species-specific volumes by timber assortment. We considered both clear cuttings and thinnings. We also investigated the accuracy of determining the dominant tree species from ALS-based volume estimates since this information is of primary interest in harvesting and silviculture operations.

\section{Materials and methods}

\subsection{Study stands and volume calculation}

Most of the stands were in southeastern Finland (Fig. 1). Stands from which Stora Enso Wood Supply Finland (WSF) purchased timber in 2013 or later were selected. About 50,000 stands were found, of which slightly more than half were thinning sites and less than half were clear-cutting sites. There were slightly less than 4000 forest stands for which forest resource information was available, but the information was not based on remote sensing in all cases.

The stand attribute information in Metsään.fi is based on the area-based interpretation approach of low pulse density (approximately 0.5 pulse $\mathrm{m}^{-2}$ ) ALS data and optical aerial image data (Finnish Forest Centre 2019a). Areal images are used to interpret the main tree species of the stand. The metrics of remote sensing data are combined with accurately measured field training data. The estimation method varies between inventory areas but usually, the $\mathrm{k}$ nearest neighbor approach is used (Maltamo and Packalén 2014). This results in tree species-specific stand attributes, such as mean diameter, basal area, and Lorey's height. By using this information, together with theoretical diameter distribution models and tree height models (Siipilehto 1999), the diameter distributions 
Fig. 1 Locations of the logging areas of this study in Finland. Source: (C) EuroGeographics for the administrative boundaries (EuroGraphics 2018).[Color online]

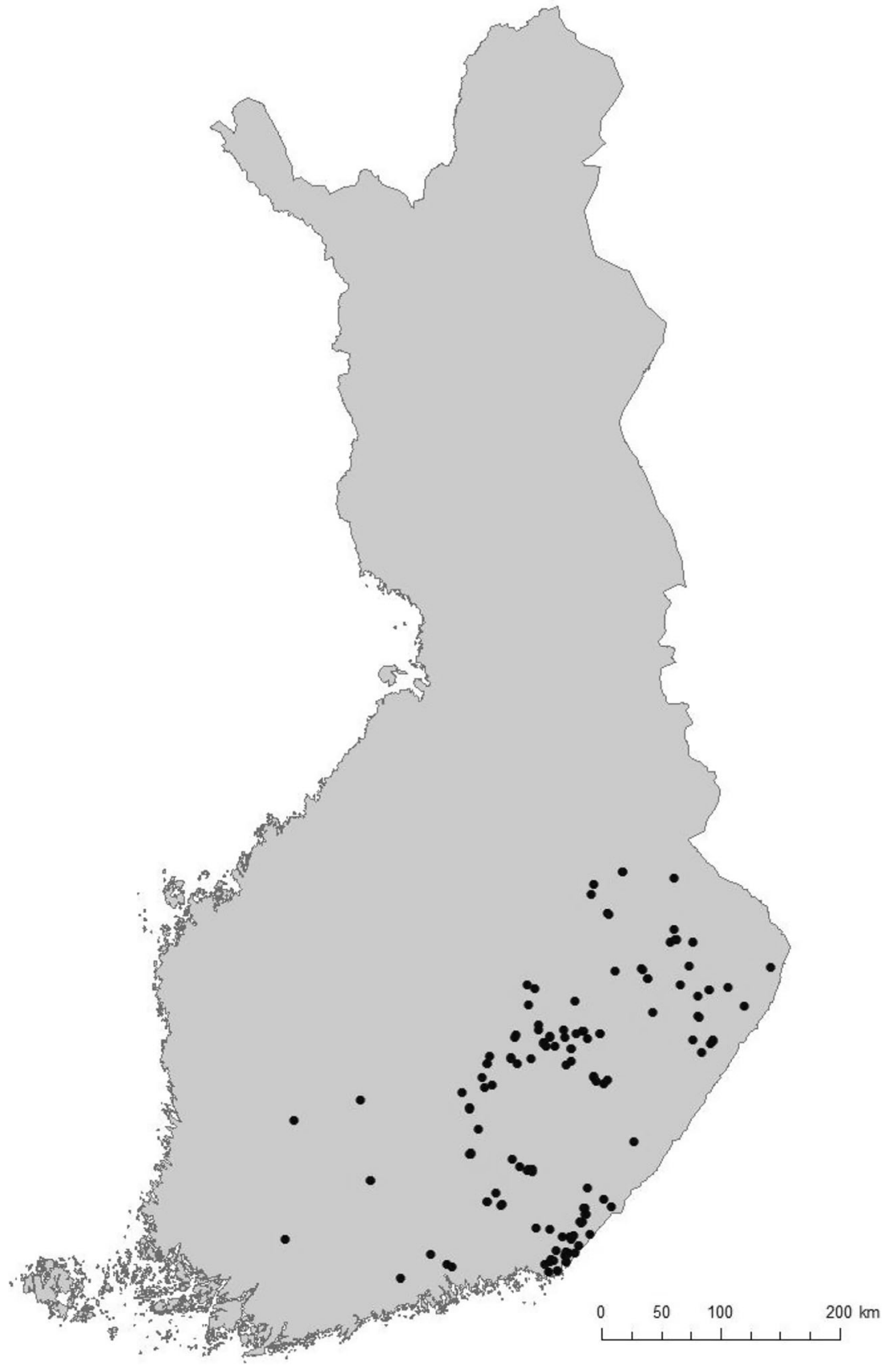

and tree heights in different diameter classes are predicted. The calculation procedure produces tree-level data, making it possible to use tree-level models in the calculation of timber assortment volumes, quality deductions and thinning removals, and update the information with the help of individual tree growth models.

The forest inventory information is updated annually using species-specific tree-level growth models (Hynynen et al. 2002). The need for thinning is evaluated based on stand basal area and dominant height, using the thinning instructions of Äijälä et al. (2019). If there is a need for thinning, i.e., basal area is higher than the thinning limit of the instruction, a thinning is simulated using the predicted diameter distribution. Trees are removed from different diameter classes until the basal area is reduced to the recommended post-thinning level. By using predicted diameters and tree heights, species-specific tree volumes and timber assortments are calculated by the taper models of Laasasenaho (1982). The minimum over-bark top diameter of sawlog or veneer log is $15 \mathrm{~cm}$ for pine, $16 \mathrm{~cm}$ for spruce, and $18 \mathrm{~cm}$ for decidious with a minimum piece length of $4 \mathrm{~m}$ for conifers and decidious. For pulpwood logs, the minimum top diameter is $7 \mathrm{~cm}$ and the minimum piece length is $2.7 \mathrm{~m}$. 
Quality deductions of sawlog volumes are calculated using Mehtätalo's (2002) models with empirical municipal correction factors. The deduction depends on the fertility, latitude, altitude, and soil type (peat vs. mineral soil) of the site, species, age, and dbh of the tree, and whether the tree is planted or of natural origin. Finally, the resulting stand attributes are wall-to-wall calculated over a continuous grid of cells, and stand results are calculated from the cell results.

Metsään.fi information was retrieved at the latest date before logging when it was available. It was verified that the stands were similar in location and area to the harvested stands. Every stand was checked individually by comparing the stand borders in Stora Enso's map system and Metsään.fi database. The harvested stands selected for the study also had to be consistent with the stand level forest inventory data produced by the Finnish Forest Centre. Harvester measurements were analyzed case-by-case using the StanForD-based harvester files (Skogforsk 2007) to verify that no abnormal harvesting had occurred.

The harvester data included information on all merchantable stem pieces cut in the stand except waste pieces of decayed wood and treetops. The volumes of harvested trees were measured by the measurement system of the harvesters. In the cutting operations of the study stands, the sawlog lengths used were mainly $3.7-5.5 \mathrm{~m}$ with the increments of $0.3 \mathrm{~m}$. Also, some shorter ( 3.1 or $3.4 \mathrm{~m}$ ) and longer $(5.8$ and $6.1 \mathrm{~m}) \log$ lengths were cut. The minimum top diameter of spruce logs was $16 \mathrm{~cm}, 15 \mathrm{~cm}$ with pine $\operatorname{logs}$, and $17 \mathrm{~cm}$ with deciduous logs. The lengths of the pulpwood logs were 2.7$5.0 \mathrm{~m}$. The minimum top diameters of spruce, pine, and deciduous pulpwood pieces were 7,6 , and $5 \mathrm{~cm}$, respectively.

Separate comparisons were made for total, pulpwood, and sawlog removals. Comparison of timber assortments was made by the tree species: Scots pine (Pinus sylvestris L.), Norway spruce (Picea abies (L.) Karst.), and deciduous trees (mainly birch (Betula spp.)). All deciduous trees were combined into one class of sawlog and pulpwood removals. Conifer species were separated since they are the dominant tree species in Finland whereas deciduous trees typically form admixtures in conifer-dominated stands. For pine and spruce, sawlog and pulpwood removals were available directly from the harvester file. It was also verified that the logging had been carried out according to the plan. If this was not the case, the stand was excluded from the study.

After removing all inconsistencies, 82 clear cuttings were selected for the study. These clear cuttings comprised 121 stands with a total area of 148.3 ha. The total growing stock volume of the stands as measured by the harvester was $40,125.2 \mathrm{~m}^{3}$. Correspondingly, 79 thinning blocks were selected for the study. They consisted of 149 stands with a total area of 223.6 ha. The total volume removed in the thinning treatments, as measured by the harvester, was $16,609.8 \mathrm{~m}^{3}$. Of the 149 thinnings, 33 represented the first commercial thinning. The mean volumes of the study data are shown in Table 1.

\subsection{Statistical analysis}

The root mean square error (RMSE) and bias (BIAS) between harvester data and Metsään.fi estimates were calculated for total volume, tree species-specific volumes, and timber assortment volumes (Eqs. 1 and 3). The corresponding relative RMSEs and biases were calculated by Eqs. 2 and 4. Finally, the correlation between the harvester data and Metsään.fi estimates was calculated using the Pearson product-moment correlation coefficient.

$$
\begin{aligned}
& \text { RMSE }=\sqrt{\sum \frac{\left(y_{\text {pred }}-y_{\text {obs }}\right)^{2}}{N},} \\
& \text { RMSE- } \%=\frac{\text { RMSE }}{\bar{y}_{\text {obs }}} 100, \\
& \operatorname{Bias}=\frac{\sum\left(y_{\text {pred }}-y_{\text {obs }}\right)}{N}, \\
& \operatorname{Bias}-\%=\frac{\text { Bias }}{\bar{y}_{\text {obs }}} 100
\end{aligned}
$$

where $y_{\text {obs }}$ is the observed value at logging site, $y_{\text {pred }}$ is the predicted value at logging site, $N$ is the number of stands, and $\bar{y}_{\text {obs }}$ is the average of observed volume.

Determining the dominant tree species is important for the planning of forest management. Usually, it is the question of separating pine- and spruce-dominated stands since deciduous-dominated stands are rare. The dominant tree species of the stand was determined by summing up the treespecific removals, both with harvester data and Metsään.fi data. Tree species with the highest harvested volume was regarded as the dominant tree species in a clear-cutting stand. The overall accuracy of the identification of dominant tree species was analyzed using the Kappa coefficient:

$K=\frac{p_{o}-p_{e}}{1-p_{e}}$

where $p_{o}$ is the proportion of correctly classified observations and $p_{e}$ is the possibility for randomly correct classification.

Landis and Koch (1977) have defined the significance of Kappa coefficient values as follows: <0 no concordance, $0-0.20$ slight, $0.21-0.40$ valid, $0.41-0.60$ moderate, $0.61-0.80$ noteworthy, and 0.81 to 1.00 almost complete concordance. 
Table 1 Mean and standard deviation of harvested total volume and timber assortment volume in Metsään.fi and harvester data in clear cutting and thinning

\begin{tabular}{|c|c|c|c|c|}
\hline \multirow[t]{2}{*}{ Cutting method and timber assortment } & \multicolumn{2}{|c|}{ Mean harvested volume $\left(\mathrm{m}^{3} \mathrm{ha}^{-1}\right)$} & \multicolumn{2}{|c|}{ Standard deviation $\left(\mathrm{m}^{3} \mathrm{ha}^{-1}\right)$} \\
\hline & Metsään.fi & Harvester & Metsään.fi & Harvester \\
\hline Clear cutting & 289.0 & 278.4 & 71.6 & 94.1 \\
\hline Pine sawlog & 42.5 & 40.85 & 40.3 & 47.08 \\
\hline Spruce sawlog & 160.9 & 131.6 & 96.7 & 89.9 \\
\hline Decidious sawlog & 8.5 & 7.5 & 11.2 & 14.7 \\
\hline Pine pulpwood & 20.5 & 21.7 & 26.6 & 24.3 \\
\hline Spruce pulpwood & 39.4 & 55.9 & 20.7 & 34.1 \\
\hline Decidious pulpwood & 17.2 & 20.6 & 24.4 & 23.8 \\
\hline Thinning & 74.4 & 74.8 & 19.8 & 30.0 \\
\hline Pine sawlog & 9.3 & 6.9 & 9.8 & 9.7 \\
\hline Spruce sawlog & 7.2 & 5.8 & 9.5 & 10.8 \\
\hline Decidious sawlog & 0.9 & 1.4 & 2.1 & 3.3 \\
\hline Pine pulpwood & 27.3 & 25.2 & 22.3 & 20.8 \\
\hline Spruce pulpwood & 15.2 & 15.5 & 18.2 & 16.3 \\
\hline Decidious pulpwood & 14.5 & 20.1 & 16.7 & 18.1 \\
\hline
\end{tabular}

\section{Results}

\subsection{Accuracy of ALS estimates in clear cutting}

In clear cuttings, the scatterplot between the total measured removal by the harvester and the estimated removal of Metsään.fi showed a quite linear relationship (Fig. 2). The RMSE of the estimated removal of Metsään.fi was $26.0 \%$
(Table 2). The bias was about $4 \%$ and the removal estimates of Metsään.fi were more often over- than underestimates. However, for very large $\left(>450 \mathrm{~m}^{3} \mathrm{ha}^{-1}\right)$ removals, Metsään.fi produced considerable underestimates (Fig. 2).

The clear-cutting stands were mostly spruce-dominated with more than two-thirds of the total removal being spruce (Table 3). In the case of spruce sawlog, there was a rather strong relationship between measured removal and the
Fig. 2 The scatterplot between the measured removal by harvester and estimated removal of Metsään.fi in clear cuttings

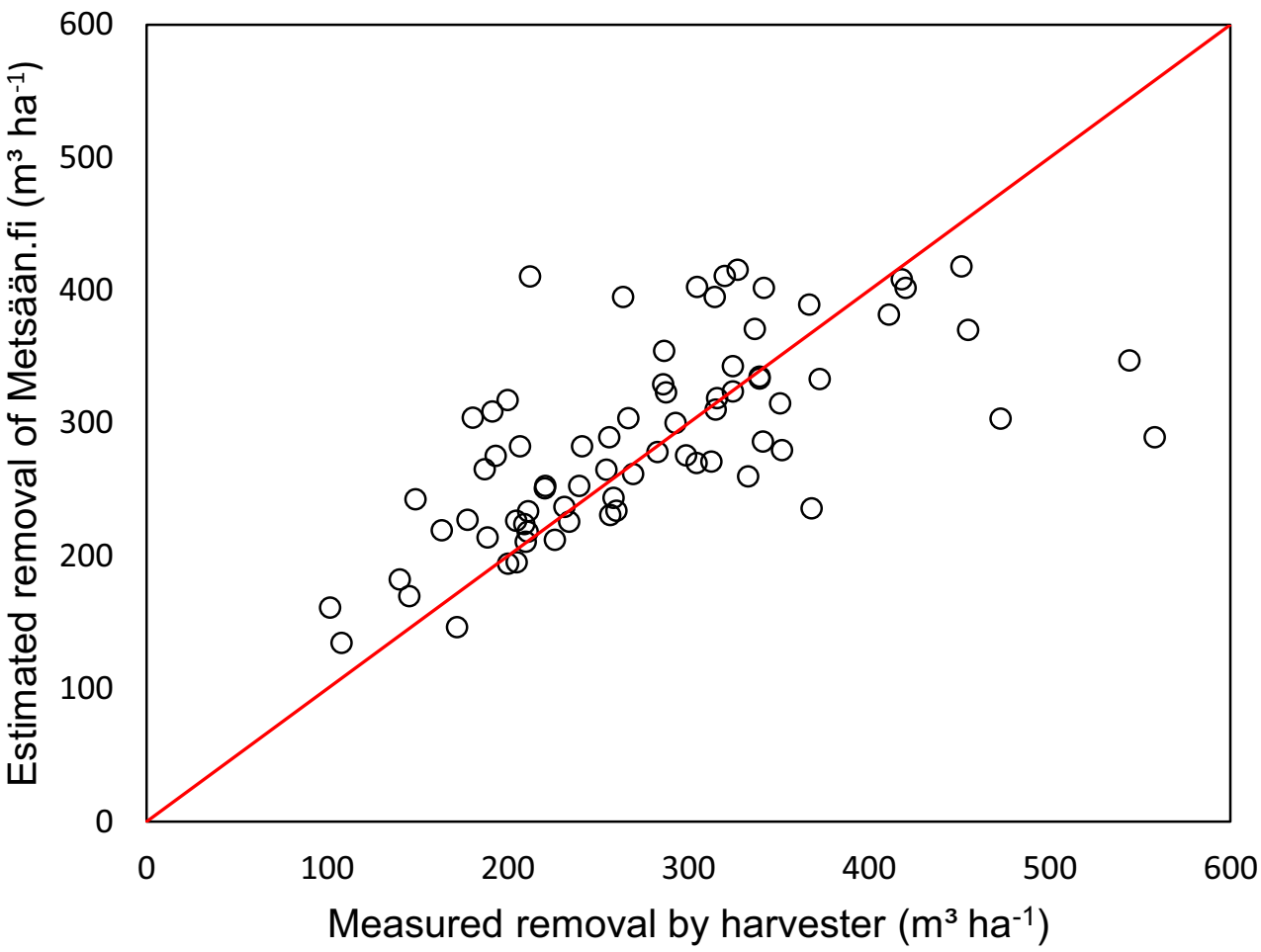


Table 2 Absolute (RMSE) and relative (RMSE\%) errors and corresponding biases (Bias, Bias\%) for total harvesting removals in clear cuttings

\begin{tabular}{llllll}
\hline & RMSE & RMSE\% & Bias & Bias\% & Correlation \\
\hline $\begin{array}{c}\text { Harvesting removal } \\
\left(\mathrm{m}^{3} \mathrm{ha}^{-1}\right)\end{array}$ & 72.39 & 26.00 & 10.60 & 3.81 & $0.65^{* *}$ \\
\hline
\end{tabular}

$* *$ Correlation statistically significant at $1 \%(p<0.01)$

estimated removal in Metsään.fi (Fig. 3). However, the RMSE\% was almost $50 \%$ and the bias was more than $20 \%$ (Table 4). The removals in Metsään.fi were overestimated, especially for spruce sawlog. The relationship was less pronounced for spruce pulpwood for which the RMSE was more than $50 \%$. The bias was about $-30 \%$, Metsään.fi estimates being lower than the realized removals of spruce pulpwood.

Less than a quarter of the total removal was pine sawlog or pulpwood (Table 3). The scatterplot between measured removal and Metsään.fi estimate showed a rather linear relationship for pine sawlog (Fig. 3). The relative RMSE was slightly less than $70 \%$ and the bias about $4 \%$ (Table 4 ). The correlation between harvester-measured removal and Metsään.fi estimate was the weakest for pine pulpwood after deciduous sawlog (Table 4). The RMSE\% was over $100 \%$ for pine pulpwood and the bias was nearly $-6 \%$. Metsään.fi produced a slight systematic underestimate for pine pulpwood removal.

In the data, the amount of deciduous removal was the smallest, less than a tenth of the total harvest. The correlation between measured and estimated removals was the lowest for deciduous sawlog (Table 4) for which the RMSE\% was almost $170 \%$ and bias about $14 \%$ (Table 4). With deciduous pulpwood, there was a significant correlation between the measured removal by the harvester and the estimated removal of Metsään.fi. The RMSE\% was slightly below $100 \%$ and the bias for decidious pulpwood removal was about $-16 \%$.

For all timber assortments, the correlation between removal measured by harvester and estimated removal of Metsään.fi was statistically significant at the $1 \%$ level. In general, sawlog removal was systematically overestimated and pulpwood volume was underestimated, most clearly in spruce. The harvest removals of the other tree species were small, and therefore,

Table 3 Total removal estimates in Metsään.fi data and the actual harvested volumes measured by harvester in clear cuttings $\left(\mathrm{m}^{3}\right)$

\begin{tabular}{lll}
\hline Tree species & Metsään.fi & Harvester \\
\hline Pine & 8367 & 7725 \\
Spruce & 24,865 & 22,845 \\
Decidious & 2535 & 2881 \\
Total & 35,756 & 33,507 \\
\hline
\end{tabular}

the absolute over- and underestimations were also small. The relative errors of the tree species-specific removals were considerably higher than obtained for the total logging removal.

In clear cuttings, the dominant tree species was interpreted correctly in $87.7 \%$ of the stands. The Kappa value was 0.7 implying that there was considerable consistency between the materials (Table 5). According to the logging data, 54 of the 73 stands were spruce-dominated and 50 of them were sprucedominated also in the Metsään.fi data. A closer inspection of the results revealed that the main tree species was classified incorrectly mainly in mixed stands. Determination of the dominant tree species was incorrect for nine stands (Table 5).

\subsection{Accuracy of ALS estimates in thinning}

At thinnings, the correlation between measured removal by the harvester and estimated removal based on ALS inventory was low (Fig. 4). The thinning removals of Metsään.fi were mostly between 50 and $100 \mathrm{~m}^{3} \mathrm{ha}^{-1}$ and included both overand underestimates. The bias was $-0.58 \%$ (Table 6 ). The correlation between removal measured by the harvester and estimated removal of Metsään.fi was considerably lower than in the case of clear cuttings but still statistically significant at the $5 \%$ level. The RMSE\% was slightly above $40 \%$. Many of the thinning stands were pine-dominated as about half of the actual removal was pine (Table 7).

\section{Discussion}

In clear cuttings, the RMSE of removal estimate of Metsään.fi was $26 \%$, which corresponds to an error of about $70 \mathrm{~m}^{3}$ per hectare. The bias was about $4 \%$ indicating that Metsään.fi slightly overestimated the removed volume. The results were less accurate than in studies where the estimate based on laser scanning was compared with the field measured value (e.g., Packalén and Maltamo 2007; Wallenius et al. 2012), most probably due to additional sources of errors such as mismatches between stand borders in Metsään.fi and the boundaries of harvest blocks. The acquisition date of the ALS data varied, and updating the data with growth models may have increased the differences between ALS-based and harvester data. Some other factors may also have caused errors. The waste pieces of decayed wood are not included in the harvester data (cf. Kärhä et al. 2019) although they are included in ALS-based estimates. The same trend has been observed also in earlier studies. For example, Hauglin et al. (2018) observed greater error rates when harvester data were used as training data for ALS-based volume prediction compared to field plot inventory-based training data.

In our study, the RMSE\% was acceptable when looking at the total harvested volume, and it seems that the Metsään.fi estimate is fairly good. In the case of thinnings, the RMSE\% 
Fig. 3 Tree species-specific scatterplots between timber assortment removals harvested (measured by harvester) and Metsään.fi estimates in clear cuttings
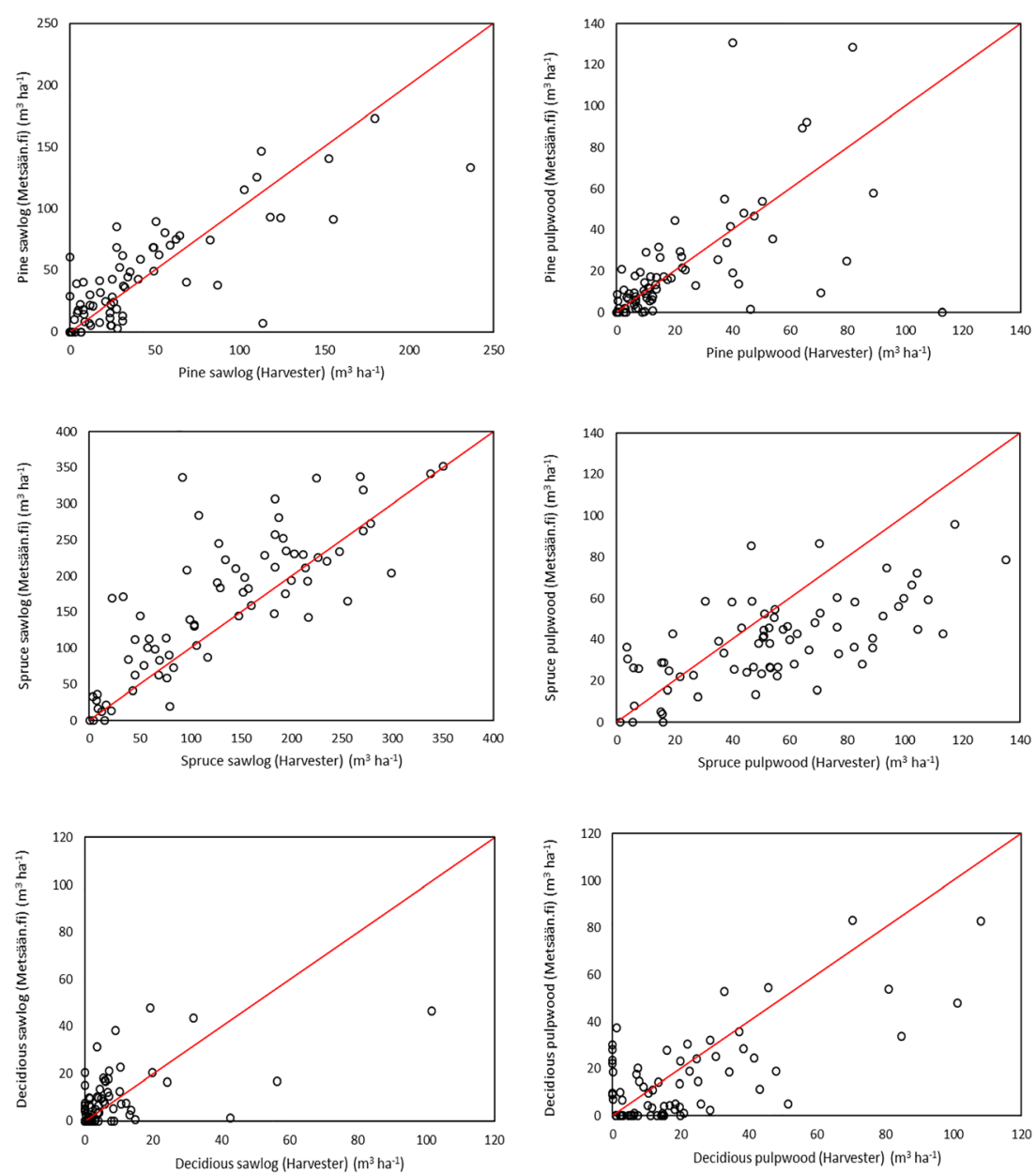

was slightly over $40 \%$, corresponding to a deviation of about $30 \mathrm{~m}^{3} \mathrm{ha}^{-1}$ between actual and estimated removal. However, the correlation between Metsään.fi estimate and true removal was low, suggesting that the thinning model applied in Metsään.fi does not produce results that reliably predict the removals of actual thinnings. The difference between the two estimates is only partly due to errors in Metsään.fi. Another reason for the differences is that the operator of the harvester

Table 4 RMSE and bias in clear cuttings by timber assortment $\left(\mathrm{m}^{3} \mathrm{ha}^{-1}\right)$

\begin{tabular}{llllll}
\hline Timber assortment & RMSE & RMSE\% & Bias & Bias\% & Correlation \\
\hline Pine sawlog & 27.42 & 67.12 & 1.60 & 3.93 & $0.81^{* *}$ \\
Spruce sawlog & 63.98 & 48.61 & 29.28 & 22.25 & $0.81^{* *}$ \\
Decidious sawlog & 12.66 & 169.80 & 1.06 & 14.25 & $0.55^{* *}$ \\
Pine pulpwood & 23.23 & 107.10 & -1.24 & -5.73 & $0.58^{* *}$ \\
Spruce pulpwood & 30.63 & 54.80 & -16.49 & -29.51 & $0.65^{* *}$ \\
Decidious pulpwood & 20.13 & 97.74 & -3.39 & -16.44 & $0.66^{* *}$ \\
\hline
\end{tabular}

*Correlation statistically significant at $5 \%(p<0.05)$

$* *$ Correlation statistically significant at $1 \%(p<0.01)$ may not follow the same thinning instructions as was used in Metsään.fi. Besides, the forest landowner (timber seller) and the procurement company may also have given thinning instructions that differ from those used in Metsään.fi.

In the dataset used in this study, the removals of highly stocked stands were underestimated in Metsään.fi. This is an interesting result since, contrary to optical imageries, ALSbased volume estimation should not underestimate large volumes (Maltamo et al. 2006). The number of observations in our study is nonetheless so small that these results cannot be generalized. The main shortcomings of ALS-based forest

Table 5 Dominant tree species according to harvester data and Metsään.fi in clear cutting sites

\begin{tabular}{llllll}
\hline & & & $\begin{array}{l}\text { Metsään.fi } \\
\text { Spruce }\end{array}$ & Decidious & Total \\
\hline \multirow{4}{*}{ Harvester } & Pine & 12 & 4 & 1 & 17 \\
& Spruce & 2 & 50 & 2 & 54 \\
& Decidious & 0 & 0 & 2 & 2 \\
& Total & 14 & 54 & 5 & \\
\hline
\end{tabular}


Fig. 4 The scatterplot between the measured removal by harvester and estimated removal of Metsään.fi in thinnings

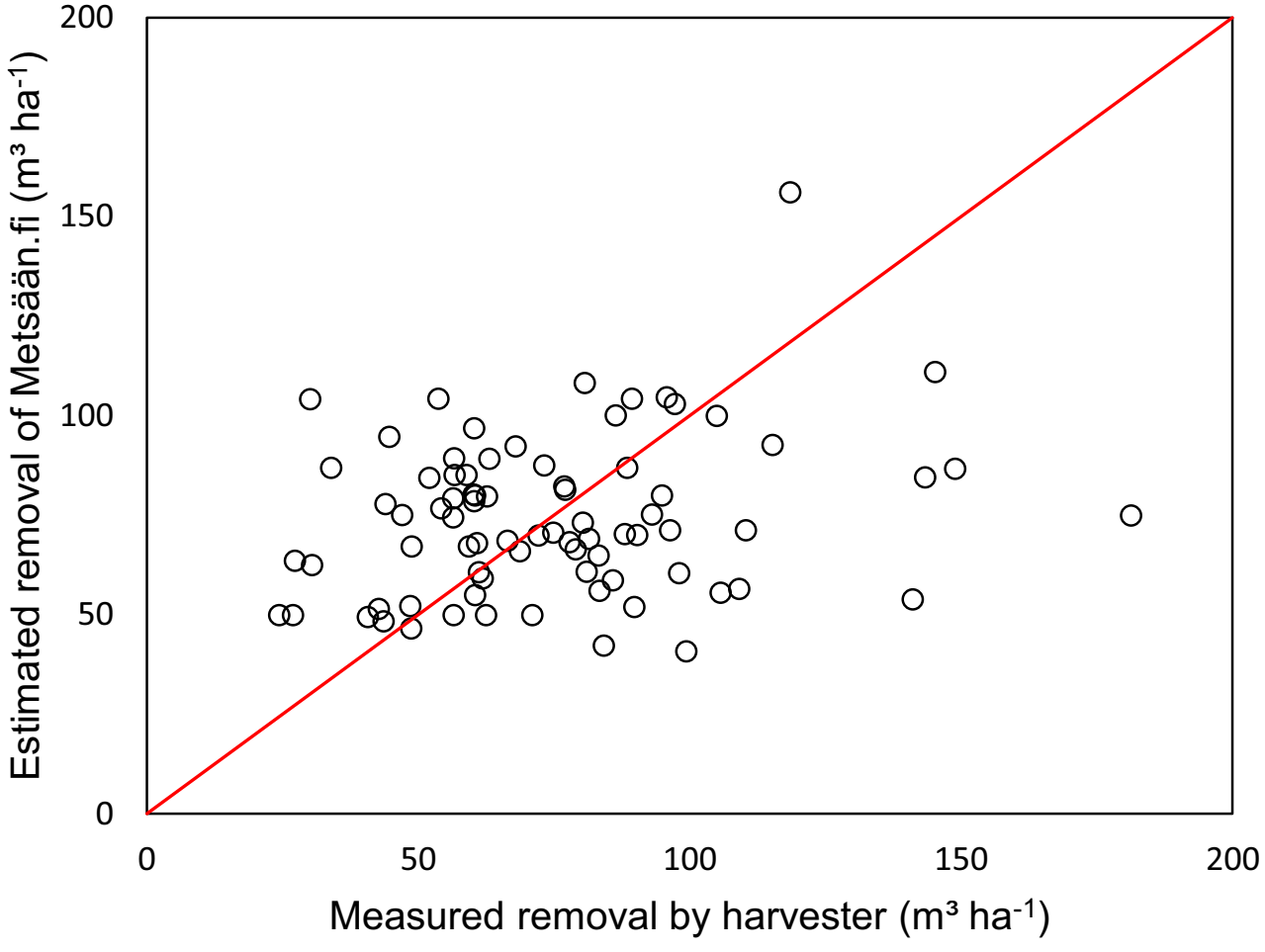

inventories are the low accuracy of tree species identification and the difficulty to predict the technical quality of the stems of trees (e.g., Wallenius et al. 2012; Næsset 2014). Also in our study, the RMSEs were considerably higher for tree speciesspecific volumes than for the total volume. ALS-based sawlog volume was overestimated, most probably mainly due to insufficient technical quality on many of the harvested stems.

Another reason for the differences in timber assortment volumes is crosscutting, which might differ in ALS-based calculation and in actual cutting. The operator of the harvester often uses manual bucking with pine and automated algorithms for spruce (Kärhä et al. 2017). Crosscutting depends on the desired distribution of different log lengths, which is ignored in the ALS-based calculation of assortment volumes.

On the other hand, the dominant tree species was interpreted correctly in approximately $90 \%$ of the stands in clear cutting, which is a high percentage. Determining the dominant tree species is usually successful with aerial photographs but determining the secondary tree species can be very challenging (Maltamo and Packalén 2014).
The vast majority of clear-cutting stands of this study located in southern Finland where spruce bark beetle (Ips typographus) is causing damage in large areas (Heino and Pouttu 2013). As a consequence of bark beetle damage, a part of log-sized spruce trees may have turned into energy wood or pulpwood. Spruce root and butt rot (Heterobasidion parviporum) is also common in the study area (Piri et al. 2017). In the case of spruce, the transition from sawlog to pulpwood was large, but it varied by region. However, the sawlog volume of the other tree species was also commonly overestimated in Metsään.fi data. Therefore, field measurements are required for all species to assess the quality properties of trees (Barth and Holmgren 2013). Wider use of harvesting data makes it possible to avoid high-cost field inventories.

In the case of thinning, larger deviations from Metsään.fi data are most likely partly due to the thinning models. Thus, based on the Metsään.fi estimate, it is not possible to realistically predict the amount of trees that are removed in actual thinnings. In Metsään.fi, determination of the dominant tree species for thinnings is not unambiguous, because some species not suitable for the site may have been removed
Table 6 Absolute and relative errors and biases for total harvesting removals in thinnings

\begin{tabular}{llllll}
\hline & RMSE & RMSE\% & Bias & Bias\% & Correlation \\
\hline Harvesting removal $\left(\mathrm{m}^{3} \mathrm{ha}^{-1}\right)$ & 31.72 & 42.41 & -0.43 & -0.58 & $0.23^{*}$ \\
\hline
\end{tabular}

*Correlation statistically significant at 5\% $(p<0.05)$

$* *$ Correlation statistically significant at $1 \%(p<0.01)$ 
Table 7 Total removal estimates in Metsään.fi and harvester data in thinnings $\left(\mathrm{m}^{3}\right)$

\begin{tabular}{lll}
\hline Tree species & Metsään.fi & Harvester \\
\hline Pine & 8987 & 8059 \\
Spruce & 4700 & 4319 \\
Decidious & 3061 & 4233 \\
Total & 16,756 & 16,609 \\
\hline
\end{tabular}

completely in the felling. On average, removals were underestimated more in thinning than clear cutting, but the bias was very low in both cases. A slight underestimation may indicate that the actual thinning is implemented slightly more intensively than suggested by the thinning models (cf. Finnish Forest Centre 2017, 2018, 2019b).

The study provided new information on the accuracy of Metsään.fi data in operational use. In conventional timber trade, remote sensing-based information still requires field verification but is useful for the purposes of timber purchasing. For example, when searching for stands with potential harvest removal, the Metsään.fi service provides useful assistance and acts as a starting point for timber trade negotiations. Future studies should develop and identify better methods to predict tree quality based on laser scanning information. Harvester data could be used in the development of these methods (Barth and Holmgren 2013).

An important topic for further research and development is how to obtain more accurate information on the quality characteristics of stands by using remote sensing data. Possibilities for wider use of harvester data should also be explored. Experiences on the use of harvester measurements as a reference for laser scanning data have been promising (Maltamo et al. 2019). However, the positioning accuracy of the data should be improved (cf. Hauglin et al. 2018). Multisource single-tree interpretation is also an interesting possibility for the future. It may combine harvester data with low-resolution remote sensing data, for example (Kankare et al. 2015).

\section{Conclusions}

The study compared, for the first time, Metsään.fi forest inventory data with the logging machine's data. It was found that Metsään.fi overestimated sawlog removals, especially the removal of spruce sawlogs in clear cuttings. Determination of the dominant tree species was accurate. Metsään.fi estimate does not realistically describe the amount of trees that are removed in actual thinnings. Further development of remote sensing-based forest inventory could rely more on data collected by harvesters, to decrease the costs of field inventories.
Acknowledgments Open access funding provided by University of Eastern Finland (UEF) including Kuopio University Hospital. We thank Mikko Kauppinen and Kari Kuusniemi from Stora Enso WSF who made the research possible and helped outline the topic. We also thank Teppo Salmi, Jukka Mustonen, and Mika Korvenranta from Stora Enso WSF for collecting the data. Special thanks also to Vesa Koskinen from Bitcomp Ltd. who was responsible for processing the Metsään.fi data.

Funding This study received financial support from Stora Enso and University of Easten Finland.

Data availability The data that support the findings of this study are available from Metsäkeskus and Stora Enso but restrictions apply to the availability of these data, which were used under license for the current study, and so are not publicly available. Data are however available from the authors upon reasonable request and with permission of Stora Enso.

\section{Compliance with ethical standards}

Conflict of interest The authors declare that they have no conflict of interest.

Open Access This article is licensed under a Creative Commons Attribution 4.0 International License, which permits use, sharing, adaptation, distribution and reproduction in any medium or format, as long as you give appropriate credit to the original author(s) and the source, provide a link to the Creative Commons licence, and indicate if changes were made. The images or other third party material in this article are included in the article's Creative Commons licence, unless indicated otherwise in a credit line to the material. If material is not included in the article's Creative Commons licence and your intended use is not permitted by statutory regulation or exceeds the permitted use, you will need to obtain permission directly from the copyright holder. To view a copy of this licence, visit http://creativecommons.org/licenses/by/4.0/.

\section{References}

Äijälä O, Koistinen A, Sved J, Vanhatalo K, Väisänen P (eds) (2019) Metsänhoidon suositukset (Recommendations of sustainable silviculture). Tapion julkaisuja

Barth A, Holmgren J (2013) Stem taper estimates based on airborne laser scanning and cut-to-length harvester measurements for pre-harvest planning. Int J For Eng 24:161-169. https://doi.org/10.1080/ 14942119.2013.858911

Bollandsås O, Maltamo M, Gobakken T, Lien V, Næsset E (2011) Prediction of timber quality parameters of forest stands by means of small footprint airborne laser scanner data. Int J For Eng 22:14 23

Breidenbach J, Næsset E, Lien V, Gobakken T, Solberg S (2010) Prediction of species specific forest inventory attributes using a nonparametric semi-individual tree crown approach based on fused airborne laser scanning and multispectral data. Remote Sens Environ 114(4):911-924. https://doi.org/10.1016/j.rse.2009.12.004

EuroGeographics (2018) Eurostat, GISCO database [online]. Available fromhttp://ec.europa.eu/eurostat/web/gisco/geodata/reference-data/ administrative-units-statistical-units/countries\#countries 14. Accessed 17 September 2019

Finnish Forest Centre (2017) Korjuujäljen tarkastusten tulokset vuodelta 2016 (Inventoring harvesting results in thinning stands in Finland, 2016). https://www.metsakeskus.fi/sites/default/files/korjuujaljentarkastustulokset-2016.pdf. Accessed 2 January 2019 
Finnish Forest Centre (2018) Korjuujäljen tarkastusten tulokset vuodelta 2017 (Inventoring harvesting results in thinning stands in Finland, 2017). https://www.metsakeskus.fi/sites/default/files/korjuujalkitulokset-2017.pdf. Accessed 2 January 2019

Finnish Forest Centre (2019a) Yleistietoa avoimesta metsätiedosta (Background information on open forest data in Finland). https:// wwwmetsaanfi/yleistietoa-avoimesta-metsatiedosta Accessed 2 January 2019

Finnish Forest Centre (2019b) Korjuujäljen tarkastusten tulokset vuodelta 2018 (Inventoring harvesting results in thinning stands in Finland, 2018). https://www.metsakeskus.fi/sites/default/files/tiedote-liitekorjuujalki-tarkastukset.pdf. Accessed 2 January 2019

Grafström A, Hedström Ringvall A (2013) Improving forest field inventories by using remote sensing data in novel sampling designs. Can J For Res 43(11):1015-1022. https://doi.org/10.1139/cjfr-2013-0123

Hauglin M, Hansen E, Sørngård E, Næsset E, Gobakken T (2018) Utilizing accurately positioned harvester data: modelling forest volume with airborne laser scanning. Can J For Res 48:913-922. https://doi.org/10.1139/cjfr-2017-0467

Heino E, Pouttu A (2013) Metsätuhot vuonna 2013 (Forest damage in Finland, 2013). Working Papers of the Finnish Forest Research Institute 295

Holmgren J, Barth A, Larsson H, Olsson H (2012) Prediction of stem attributes by compining airborne laser scanning and measurements from harvesters. Silva Fenn 46:227-239. https://doi.org/10.14214/ sf.56

Holopainen M, Hyyppä J, Vastaranta M (2013) Laserkeilaus metsävarojen hallinnassa (Laser scanning in the management of forest resources). Helsingin yliopiston metsätieteiden laitoksen julkaisuja 5:1-75

Hynynen J, Ojansuu R, Hökkä H, Siipilehto J, Salminen H, Haapala P (2002) Models for predicting stand development in MELA System. Working Papers of the Finnish Forest Research Institute 835

Kankare V, Liang X, Vastaranta M, Yu X, Holopainen M, Hyyppä J (2015) Diameter distribution estimation with laser scanning based multisource single tree inventory. ISPRS J Photogram Remote Sens 108:161-171. https://doi.org/10.1016/j.isprsjprs.2015.07.007

Kärhä K, Änäkkälä J, Hakonen O, Palander T, Sorsa JA, Räsänen T, Moilanen T (2017) Analyzing the antecedents and consequences of manual log bucking in mechanized wood harvesting. Mech Mater Sci Eng 12:1-15. https://doi.org/10.2412/mmse.45.20.957

Kärhä K, Räsänen M, Palander T (2019) The profitability of cross-cutting practices in butt-rotten Picea abies final-felling stands. Forests 10: 874. https://doi.org/10.3390/f10100874

Korpela I, Ørka HO, Maltamo M, Tokola T, Hyyppä J (2010) Tree species classification using airborne LiDAR effects of stand and tree parameters, downsizing of training set, intensity normalization and sensor type. Silva Fenn 44:319-339. https://oi.org/10.14214/sf.156

Laasasenaho J (1982) Taper curve and volume functions for pine, spruce and birch. Communicationes Instituti Forestalis Fenniae 838

Landis JR, Koch GG (1977) The measurement of observer agreement for categorical data. Biometrics 33:159-174

Lindroos O, Ringdahl O, La Hera P, Hohnloser P, Hellström T (2015) Estimating the position of the harvester head - a key step towards the precision forestry of the future? Croat J For Eng 36:147-164

Malinen J, Maltamo M, Verkasalo E (2003) Predicting the internal quality and value of Norway spruce trees by using two non-parametric nearest neighbor methods. For Prod J 53:85-94

Maltamo M, Packalén P (2014) Species-specific management inventory in Finland. In: Maltamo M, Næsset E, Vauhkonen J (eds) Forestry applications of airborne laser scanning: concepts and case studies. Managing Forest Ecosystems 27. Springer, pp 241-252

Maltamo M, Malinen J, Packalén P, Suvanto A, Kangas J (2006) Nonparametric estimation of stem volume using laser scanning, aerial photography, and stand-register data. Can J For Res 36:426-436. https://doi.org/10.1139/x05-246
Maltamo M, Hauglin KM, Næsset E, Gobakken T (2019) Estimating stand level stem diameter distribution utilizing accurately positioned tree-level harvester data and airborne laser scanning. Silva Fenn 53: 10075. https://doi.org/10.14214/sf.10075

Mehtätalo L (2002) Valtakunnalliset puukohtaiset tukkivähennysmallit männylle, kuuselle, koivuille ja haavalle (National tree-level sawlog reduction models for Norway spruce, Scots pine, birch and aspen). Metsätieteen aikakauskirja 4(2002):575-591

Næsset E (2007) Airborne laser scanning as a method in operational forest inventory: Status of accuracy assessments accomplished in Scandinavia. Scand J For Res 22(5):433-442. https://doi.org/10. 1080/02827580701672147

Næsset E (2014) Area-based inventory in Norway - from innovation to an operational survey. In: Maltamo M, Næsset E, Vauhkonen J (eds) Forestry applications of airborne laser scanning: concepts and case studies. Managing Forest Ecosystems 27. Springer, pp 215-240

Ørka HO, Dalponte M, Gobakken T, Næsset E, Ene LT (2013) Characterizing forest species composition using multiple remote sensing data sources and inventory approaches. Scand J For Res 28(7):677-688. https://doi.org/10.1080/02827581.2013.793386

Packalén P (2009) Using airborne laser scanning data and digital aerial photographs to estimate growing stock by tree species. Dissertationes Forestales 77

Packalén P, Maltamo M (2007) The k-MSN method in the prediction of species specific stand attributes using airborne laser scanning and aerial photographs. Remote Sens Environ 109:328-341. https://doi. org/10.1016/j.rse.2007.01.005

Pesonen M (2017) Metsäkeskuksen hilatiedon ja Luonnonvarakeskuksen kokojakaumamallin tarkkuus puujoukon luonnissa (the accuracy of predicting tree size distribution using the grid cell level data of Finnish Forest Centre and the diameter distribution model of the Natural Resources Institute Finland). Pro gradu -tutkielma, Helsingin yliopisto, Maatalous-metsätieteellinen tiedekunta, Metsätieteiden laitos

Peuhkurinen J, Maltamo M, Malinen J, Pitkänen J, Packalén P (2007) Preharvest measurement of marked stands using airborne laser scanning. For Sci 53:653-661

Peuhkurinen J, Mehtätalo L, Maltamo M (2011) Comparing individual tree detection and the area-based statistical approach for the retrieval of forest stand characteristics using airborne laser scanning in Scots pine stands. Can J For Res 41:583-598. https://doi.org/10.1139/ $\mathrm{X} 10-223$

Piri T, Selander A, Hantula J (2017) Juurikääpätuhojen tunnistaminen ja torjunta (Identifying and prevention of Heterobasidion spp. root and butt-rot damage). Finnish Forest Centre

Saukkola A, Melkas T, Riekki K, Sirparanta S, Peuhkurinen J, Holopainen M, Hyyppä J, Vastaranta M (2019) Predicting forest inventory attributes using airborne laser scanning, aerial imagery, and harvester data. Remote Sens 11:797. https://doi.org/10.3390/ rs11070797

Siipilehto J (1999) Improving the accuracy of predicted basal-area diameter distribution in advanced stands by determining stem number. Silva Fenn 33:650. https://doi.org/10.14214/sf.650

Siipilehto J, Lindeman H, Vastaranta M, Xiaowei Y, Uusitalo J (2016) Reliability of the predicted stand structure for clearcut stands using optional methods: airborne laser scanning-based methods, smartphone-based forest inventory application Trestima and preharvest measurement tool EMO. Silva Fenn 50:1568. https://doi. org/10.14214/sf. 1568

Silva CA, Hudak AT, Vierling LA, Loudermilk EL, O'Brien JJ, Hiers JK, Jack SB, Gonzalez-Benecke C, Lee H, Falkowski MJ, Khosravipour A (2016) Imputation of individual longleaf pine (Pinus palustris Mill.) tree attributes from field and LiDAR data. Can J Remote Sens 42(5):554-573. https://doi.org/10.1080/07038992.2016. 1196582 
Skogforsk (2007) StanForD: Standard for forest data and communications. http://www.skog forsk.se/contentassets/ b063db555a664ff8b515ce121f4a42d1/stanford_main-doc_070327. pdf. Accessed on 2 January 2019

Suvanto A, Maltamo M, Packalén P, Kangas J (2005) Kuviokohtaisten puustotunnusten ennustaminen laserkeilauksella (Estimating standspecific attributes with laser scanning data). Metsätieteen aikakauskirja 4(2005):413-428

Vauhkonen J (2010) Estimating single-tree attributes by airborne laser scanning: methods based on computational geometry of the 3-D point data. Dissertationes Forestales 104

Wallenius T, Laamanen R, Peuhkurinen J, Mehtätalo L, Kangas A (2012) Analysing the agreement between an airborne laser scanning based forest inventory and a control inventory - a case study in the state owned forests in Finland. Silva Fenn 46:111-129. https://doi.org/10. $14214 /$ sf.69

White JC, Wulder MA, Varhola A, Vastaranta M, Coops NC, Cook BD, Pitt D, Woods M (2013) A best practices guide for generating forest inventory attributes from airborne laser scanning data using an areabased approach. Forest Chronicle 89(6):722-723. https://doi.org/10. 5558/tfc2013-132

Yao W, Krzystek P, Heurich M (2012) Tree species classification and estimation of stem volume and DBH based on single tree extraction by exploiting airborne full-waveform LiDAR data. Remote Sens Environ 123:368-380. https://doi.org/10.1016/j.rse.2012.03.027

Publisher's note Springer Nature remains neutral with regard to jurisdictional claims in published maps and institutional affiliations. 